\title{
PENGAPLIKASIAN METODE FUZZY ANALYTIC HIERARCHY PROCESS (FAHP) PADA PENENTUAN PIMILIHAN SUPPLIER BENANG (Studi Kasus di CV. Sarung Indah Sejahterah)
}

\author{
Syamsul Huda ${ }^{(1)}$, Pregiwati Pusporini( ${ }^{(2)}$, Said Salim Dahda ${ }^{(3)}$ \\ ${ }^{1}$ Mahasiswa Teknik Industri, Fakultas Teknik, Universitas Muhammadiya Gresik \\ ${ }^{2,3}$ Dosen Teknik Industri, Fakultas Teknik, Universitas Muhammadiyah Gresik Jl. Sumatera No. 101 \\ GKB-Gresik 61121. \\ e-mail : Syamsulhuda53@gmail.com
}

\begin{abstract}
ABSTRAK
Pemilihan supplier merupakan salah satu aktivitas dalam rangkaian pekerjaan CV Sarung Indah Sejahtera. Aktivitas ini dikategorikan dalam aktivitas strategis, karena peran supplier akan turut dalam menentukan keberhasilan perusahaan, apabila barang yang disediakan supplier tidak sesuai dengan kebutuhan perusahaan, maka dapat dipastikan bahwa proses pekerjaan akan terganggu. Berpijak dari latar belakang tersebut maka tujuan dari penelitian ini adalah menentukan supplier yang dapat memberikan perfomansi terbaik, berdasarkan kriteria dan subkriteria yang telah ditentukan perusahaan. CV Sarung Indah Sejahterah adalah sebuah perusahaan yang memproduksi dan menjual sarung tenun tangan tanpa mesin, sehingga kualitas menjadi hal yang sangat penting. Penelitian ini melibatkan lebih dari satu kriteria dalam menentukan supplier, agar dapat membuat keputusan yang tepat maka diperlukan metode Multi Criteria Decision Making (MCDM). Metode yang digunakan disini adalah metode Analytical Hierarchy Process (AHP) dan Fuzzy Set, yang untuk selanjutnya disebut dengan metode Fuzzy Analytical Hierarchy Process (FAHP). Yaitu ketidakmampuan dalam mempertimbangkan ketidakpastian yang muncul akibat subjektivitas manusia. Hasil penenelitian menenjukkan bahwa tedapat 4 kriteria yang harus dipertimbangkan dalam menentukan supplier di CV Sarung Indah Sejahterah. Keempat kriteria tersebut adalah pengiriman, kualitas, pelayanan, harga. Hasil dari tahap an metode Fuzzy Analytical Hierarchy Process (FAHP). Didapatkan urutan sebagai berikut : Supplier 1 BNP 101,813, Supplier 2 BNP 117,29, Supplier 3 BNP 99,59.
\end{abstract}

Kata kunci : Supplier, Kriteria pemilihan supplier, perbandingan berpasangan, Fuzzy Analytical Hierarchy Process (FAHP).

\section{PENDAHULUAN}

Semua aktivitas di suatu perusahaan merupakan suatu mata rantai yang saling terhubung. Tujuan dari semua bagian perusahaan diantaranya yaitu meningkatkan kinerja, kualitas, serta kuantitas produk. Pada umumnya persaingan industri yang ketat dan tingginya ekspektasi konsumen dalam era reformasi, menjadikan perusahaan harus berputar otak untuk menyusun kembali strategi dalam memenangkan persaingan bisnis. Selain itu semakin ketatnya persaingan bisnis maka perusahaan semakin sadar bahwa kunci keberhasilan dalam bisnis tidak hanya ditentukan oleh aspek internal, namun juga aspek eksternal seperti supplier (Tandelilin, 2010).

Salah satu faktor kesuksesan sebuah perusahaan adalah pemilihan supplier. Pada pemilihan supplier yang tepat dapat menjamin ketersediaan bahan baku untuk menjaga lintasan produksi. Selain itu, pemilihan supplier ini dapat dikatakan sebagai salah satu aktivitas penting pada bagian pengadaan untuk mencapai keunggulan bersaing. Untuk mendapatkan kinerja rantai pasok yang maksimal harus menggabungkan kriteria lain yang relevan dengan tujuan perusahaan. Berikut terdapat beberapa kriteria yang mempengaruhi dalam pemilihan supplier, misalnya dalam hal kualitas yang meliputi pengiriman, kinerja masa lalu, garansi, harga, kemampuan teknik, dan kondisi finansial.

Berbicara tentang pemilihan supplier, CV. Sarung Indah Sejahterah ini termasuk perusahaan yang bergerak di bidang produksi sarung tenun tangan yang dijadikan sebagai topik masalah dalam penelitian ini. CV. Sarung Indah Sejahterah memperoleh bahan baku dari beberapa supplier untuk memenuhi keperluan produksi. Dalam produksinya CV. Sarung Indah Sejahterah akan memilih pemasok yang mampu memberikan spesifikasi material yang diinginkan dengan harga yang kompetitif untuk memenuhi pesanan. Dalam prakteknya sering bahan baku diperoleh dari beberapa supplier tergantung hanya pada harga yang ditawarkan. Namun seiring dengan persaingan yang semakin ketat, perusahaan dituntut tidak hanya mempertimbangan harga namun juga kriteria lain seperti kualitas, service, pelayanan dan garansi. Berikut data pemakaian 
bahan baku benang CV. Sarung Indah Sejahterah pada bulan Mei sampai dengan bulan Oktober 2017 :

Tabel 1 Data Pemakaian Bahan Baku

Benang
\begin{tabular}{|c|c|c|c|c|c|c|}
\hline $\begin{array}{l}\text { Jenis } \\
\text { bena } \\
\text { ng }\end{array}$ & \multicolumn{7}{|c|}{ Bulan } \\
\cline { 2 - 7 } & & Juni & Juli & Agt & Sep & Okt \\
\hline Suter & 30 & 30 & 35 & 30 & 25 & 30 \\
a 140 & $\mathrm{~kg}$ & $\mathrm{~kg}$ & $\mathrm{~kg}$ & $\mathrm{~kg}$ & $\mathrm{~kg}$ & $\mathrm{~kg}$ \\
\hline Suter & 45 & 40 & 40 & 40 & 35 & 40 \\
a 210 & $\mathrm{~kg}$ & $\mathrm{~kg}$ & $\mathrm{~kg}$ & $\mathrm{~kg}$ & $\mathrm{~kg}$ & $\mathrm{~kg}$ \\
\hline Mesr & 60 & 70 & 60 & 65 & 60 & 70 \\
es & $\mathrm{kg}$ & $\mathrm{kg}$ & $\mathrm{kg}$ & $\mathrm{kg}$ & $\mathrm{kg}$ & $\mathrm{kg}$ \\
$80 / 2$ & & & & & & \\
\hline $\begin{array}{c}\text { Mesr } \\
\text { es }\end{array}$ & 120 & 110 & 125 & 120 & 130 & 120 \\
100 & $\mathrm{~kg}$ & $\mathrm{~kg}$ & $\mathrm{~kg}$ & $\mathrm{~kg}$ & $\mathrm{~kg}$ & $\mathrm{~kg}$ \\
\hline
\end{tabular}

Tabel diatas dapat di lihat bahwa kebutuhan bahan baku benang pada CV. Sarung Indah Sejahtera didapatkan tingkat konsumsi tertinggi yaitu pada pemakaian benang jenis mesres type 100. Hal ini harus dilakukan dengan kerjasama dengan berbagai supplier untuk menyuplai jenis bahan baku tersebut. Jika tidak maka dikhawatirkan dapat menghambat proses produksi dan dapat menimbulkan kerugian bagi perusahaan. (Yudrifil Dan Ahmad Tri Syarifudin 2013) (Agarwal Dan Ravi 2005).

Adanya permasalahan tersebut, perusahaan pasti membutuhkan sebuah metode pengambilan keputusan dalam pemilihan supplier terbaik. Metode yang digunakan yaitu "Analitical Hierarchy Process" (AHP) yang merupakan salah satu model pengambilan keputusan yang sering digunakan untuk mengatasi permasalahan multikriteria. Pada dasarnya AHP adalah salah satu teori umum tentang pengukuran yang digunakan untuk menemukan skala rasio baik dari perbandingan berpasangan yang diskrit maupun kontinu (Sri Mulyono, 1996). Namun, meskipun terbilang demikian terkadang metode tersebut sangat susah untuk menilai suatu kriteria dalam angka yang pasti. Untuk itulah AHP disempurnakan dengan Fuzzy AHP yang merupakan penggabungan dari teknik AHP dan logika matematika fuzzy (Kusumadewi 2004). Dengan demikian diharapkan penelitian menggunakan metode “Analitical Hierarchy
Process" (AHP) dan fuzzy" ini mampu menunjang keputusan yang akan diambil oleh CV. Sarung Indah Sejahterah untuk memilih supplier terbaik.

\section{LANDASA TEORI}

\subsection{Kriteria Pemilihan Supplier}

Seleksi Supplier merupakan salah satu isu yang paling penting dari perusahaan yang harus dipertimbangkan secara seistematis para pengambil keputusan. Sebuah perusahaan yang memutuskan untuk membeli bahan ketimbang membuatnya harus memilih Supplier

Salah satu hasil penelitian yang dilakukan oleh dickson yang lebih dikenal dengan Dickson's Vendor selevtion Criteria. Dimana kriteria dalam pemilihan Supplier dibagi menjadi 23 kriteria yang terlihat pada tabel 2.1 (Weber CA \& Benton WC 1991).

\subsection{Metode Analytical Hierarchy Process (AHP)}

Metode Analytical Hierarchy Process (AHP) merupakan satu model yang fleksibel yang memungkinkan orang per orang atau kelompok untuk membentuk gagasan - gagasan dan membatasi masalah dengan asumsi mereka sendiri dan menghasilkan solusi yang bagi mereka.

Proses ini bergantung pada imajinasi, pengalaman dan pengetahuan untuk menyusun hierarki suatu masalah dan pada logika, intuisi, pengalaman, pengetahuan untuk memberi pertimbangan. Setelah diterima dan diikuti, AHP menunjukkan bagaimana menghubungkan elemen - elemen dari dari bagian lain untuk memperoleh ghasil gabungan. Prosesnya adalah mengidentifikasi, memahami, dan menilai interaksi - interaksi dari suatu sistem sebagai satu keseluruhan. Analytical Hierarchy Process (AHP) mempunyai landasan aksiomatik yang terdiri dari dari:

\section{Resiprocal Comparison}

Mengandung arti bahwa matrix berpasangan yang terbentuk harus bersifat berkebalikan. Misalnya, jika A adalah $k$ kali lebih penting dari pada B maka B adalah $1 / k$ kali lebih penting dari A.

2. Homegenity

Mengandung arti kesamaan dalam melakukan perbandingan. Misalnya, tidal memungkinkan jeruk dibandingkan dengan 


\begin{tabular}{|c|c|c|}
\hline No & Kriteria & Keterangan \\
\hline 1 & Quality & $\begin{array}{l}\text { Kualitas Barang } \\
\text { yang ditawarkan }\end{array}$ \\
\hline 2 & Delivry & $\begin{array}{c}\text { Waktu Pengiriman } \\
\text { barang }\end{array}$ \\
\hline 3 & $\begin{array}{l}\text { Performance } \\
\text { History }\end{array}$ & $\begin{array}{l}\text { Histori Performa } \\
\text { supplier }\end{array}$ \\
\hline 4 & $\begin{array}{l}\text { Warranties \& } \\
\text { Clain Product }\end{array}$ & $\begin{array}{l}\text { Garansi dan } \\
\text { Layanan } \\
\text { Pengaduan }\end{array}$ \\
\hline 5 & $\begin{array}{l}\text { Productions } \\
\text { Facilities \& } \\
\text { Capacities }\end{array}$ & $\begin{array}{c}\text { Kapasitas dan } \\
\text { Fasilitas Produksi }\end{array}$ \\
\hline 6 & Price & $\begin{array}{c}\text { Harga Barang yang } \\
\text { ditawarkan }\end{array}$ \\
\hline 7 & $\begin{array}{c}\text { Technical } \\
\text { Capabilities }\end{array}$ & $\begin{array}{c}\text { Kemampuan } \\
\text { Bisnis }\end{array}$ \\
\hline 8 & $\begin{array}{l}\text { Finansial } \\
\text { Positions }\end{array}$ & $\begin{array}{l}\text { Posisi Keuangan } \\
\text { Perusahaan }\end{array}$ \\
\hline 9 & $\begin{array}{l}\text { Procedural } \\
\text { Compliance }\end{array}$ & $\begin{array}{l}\text { Prosedur } \\
\text { Pengadaan }\end{array}$ \\
\hline 10 & $\begin{array}{l}\text { Communication } \\
\text { System }\end{array}$ & $\begin{array}{c}\text { Sistem } \\
\text { Komunikasi }\end{array}$ \\
\hline 11 & $\begin{array}{l}\text { Reputation \& } \\
\text { Position }\end{array}$ & $\begin{array}{l}\text { Posisi dan } \\
\text { Reputasi } \\
\text { Perusahaan }\end{array}$ \\
\hline 12 & $\begin{array}{l}\text { Desire of } \\
\text { Business }\end{array}$ & Jiwa Bisnis \\
\hline 13 & $\begin{array}{c}\text { Management \& } \\
\text { Organization }\end{array}$ & $\begin{array}{c}\text { Menejemen dan } \\
\text { Organisasi }\end{array}$ \\
\hline 14 & Operating Control & $\begin{array}{c}\text { Control Dan } \\
\text { Pengoperasian }\end{array}$ \\
\hline 15 & Repair servise & $\begin{array}{c}\text { Perbaikan } \\
\text { Pelayanan yang } \\
\text { ditawarkan }\end{array}$ \\
\hline 16 & Attitude & $\begin{array}{l}\text { Perilaku supplier } \\
\text { kekonsumen }\end{array}$ \\
\hline 17 & Packaging Ability & $\begin{array}{l}\text { Kemampuan } \\
\text { Pengemasan }\end{array}$ \\
\hline 18 & $\begin{array}{c}\text { Labor Relation } \\
\text { Record }\end{array}$ & $\begin{array}{c}\text { Hubungan Dengan } \\
\text { Pegawai }\end{array}$ \\
\hline 19 & $\begin{array}{l}\text { Geographical } \\
\text { Location }\end{array}$ & Lokasi Geografis \\
\hline 20 & $\begin{array}{c}\text { Amount of Pas } \\
\text { Business }\end{array}$ & $\begin{array}{l}\text { Jumlah Bisnis } \\
\text { Sebelumnya }\end{array}$ \\
\hline 21 & Training Aids & Bantuan Pelatihan \\
\hline 22 & $\begin{array}{c}\text { Reciproval } \\
\text { Arrangements }\end{array}$ & $\begin{array}{c}\text { Adanya Hubungan } \\
\text { Timbal Balik }\end{array}$ \\
\hline
\end{tabular}

bola tenisdalam hal rasa, tetapi akan lebih relevan jika dibandingkan dalam hal berat.

3. Dependence

berarti bahwa setiap jenjang (level) memiliki kaitan (complete hierarchy) walaupun mungkin saja terjadi hubungan yang tidak sempurna (incoplete hierarchy).

4. Expectation

Artinya menonjolkan penilaian yang bersifat ekspektasi dan preferensi dari pengambilan keputusan. Penilaian dapat berupa data kuantitatif maupun yang bersifat kualitatif.

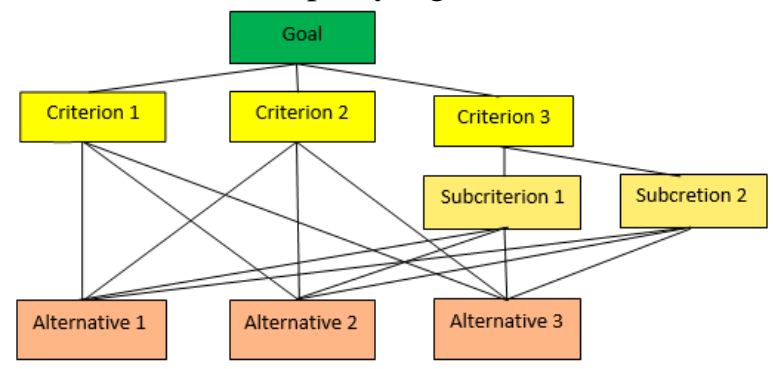
AHP

Gambar 1 contoh problem hierarchy pada

Ada tiga dasar dari AHP yaitu :

1. Menggambarkan dan menguraikan secara hierarkis yang kita sebut menyusun secara hierarki - yaitu memecah - mecah persoalan menjai unsur - unsur atau kriteria - kriteria yang lebih kecil.

2. Penetapan prioritas dan sintesis, yang kita sebut penetapan prioritas, yaitu menentukan peringkat prioritas elemen - elemen menurit relativtas kepentingannya.

3. Konsistensi logis - yaitu, menjamin bahwa semua elemen dikelompokkan secara logis dan diperingkatkan secara konsisten sesuai dengan suatu kriteria yang logis.

Manfaat dan keuntungan dari AHP (Muhammad Rif'an 2014)

1. Kesatuan

AHP memberi satu model tunggal yang mudah dimengerti dan ini merupakan satu kesatuan, luwes untuk aneka ragam persoalan tak terstruktur

2. Kompleksitas

AHP memadukan ancangan deduktif dan ancangan berdasarkan sistem dalam memecahkan persoalan kompleks.

3. Saling ketergantungan 
AHP dapat menangani saling ketergantungan elemen-elemen dalam suatu sistem dan tak memaksakan pemikiran linear.

4. Penyusunan hierarki

AHP mencermikan kecenderungan alami pikiran untuk memilah -milah elemen - elemen suatusistem dalam berbagai tingkat berlainan dan mengelompokkan unsur yang serupa dalam setiap tingkat.

5. Pengukuran

AHP memberikan suatu skala untuk mengatur hal -hal dan wujud suatu metode untuk menetapkan prioritas.

6. Konsitensi

AHP melacak konsistensi logis dan pertimbangan - pertimbangan yang digunakan dalam menetapkan berbagai prioritas.

7. Sintesis

AHP menuntun ke suatu taksiran menyeluruh tentang kebaikan setiap alternatif.

8. Tawar menawar

AHP mempertimbangkan prioritas - prioritas relatif dari berbagai faktor system dan memungkinkan orang memilih alternatif terbaik berdasarkan tujuan-tujuan mereka.

9. Penilaian dan konsensus

AHP tidak memaksakan konsensus tetapi mensistensis suatu hasil yang representatif dari berbagai penilaian yang berbeda-beda.

10.Pengulangan proses

AHP memungkinkan orang memperhalus definisi mereka kepada suatu persoalan dan memperbaiki pertimbangan dan pengertian mereka melalui pengulangan.

\subsection{Fuzzy Analytical Hierarchy Process}

(F-AHP)

Alat bantu pengambilan keputusan bisanya bertujuan untuk dapat mengakomodir konflik pendapat dan subjektivitas dari penilaian beberapa orang yang berbeda. Tidak seperti pengambilan keputusan sederhana (yang hanya terdiri dari satu kriteria), pada dunia nyata pastila banyak kriteria dan alternatif yang terlibat dalam pengambilan keputusan. Hal ini membuat proses pengambilan keputusan semakin rumit karena karena terjadinya konflik pendapat seperti ketidaksamaan pendapat mengenai tingkat prioritas dari setiap kriteria. Oleh karena itu AHP yang mampu memecah menjadi elemen - elemen yang lebih kecil dalam bentuk hierarki yang lebih sederhana dinilai dapat digunakan untuk pengambilan keputusan dengan jumlah kriteria yang lebih dari satu atau yang sering disebut Multi Criteria Decision Making (MCDM).

Terdapat beberapa variasi FAHP dan berikut merupakan beberapa jenis FAHP yang telah dikembangkan (Muhammad Rif'an 2014):

1. Var Laarhoven dan Pedryez (1983) merupakan triangural fuzzy number pada rasio perbandingan berpasangan. Hal ini yang mengawali munculnya metode Fuzzy AHP.

2. Kristianto (2002) mengajukan suatu model FAHP yang berbasis pada Fuzzy quantification theory dimana aspirasi para evaluator yang berbentuk crisp diubah menjadi bentuk fuzzy untuk dicari fungsi keanggotaannya. Model ini masih menganggap aspirasi evaluator crisp dan metode pengkuantisiran melibatkan operasi komputasi yang rumit.

3. Raharjo (2002) mengajukan model FAHP dengan model pembobotan non-additive yang merupakan gabungan dari bobot prior dan bobot informasi. Bobot prior adlah bobot fuzzy pengembangan AHP dan bobot informasi dari pembobotan fuzzy entropy. Model tersebut menggunakan satu evaluator dan pembobotan fuzzy-nya melibatkan operasi kompetasi yang rumit.

Singgih (2005) mengajukan model FAHP yang merupakan pengembangan dari Rahardjo (2002) dimana dapat menggunakan lebih satu evaluator.

\section{METODOLOGI PENELITIAN}

3.1 Pengumpulan Data

Pada tahap ini peneliti akan mengumpulkan data yang akan dibutuhkan untuk penelitian ini. Peneliti mengumpulkan data dengan cara diskusi brainstorming dan menyebar kuisioner guna mencari tahu faktor-faktor yang terlibat, faktorfaktor berpengaruh, serta alternatif yang akan disarankan pada perusahaan untuk menentukan supplier terbaik untuk CV. Sarung Indah Sejahterah.

\section{PENGUMPULAN DAN PENGELOLAHAN DATA}

\subsection{Data Kriteria dan Responden}

Berdasarkan Dickson's Vender Selection Criteria, (Weber CA \& Benton WC). terdapat 23 kriteria - kriteria yang bisa digunakan untuk pengambilan keputusan pemilihan supplier. Kemudian kriteria-kriteria tersebut divalidasi sesuai dengan kebutuhan pihak perusahaan. 
terdapat 4 kriteria yang digunakan dalam penelitian ini, yaitu Delivery, Kualitas, pelayanan, dan Harga. Penetapan kriteria yang digunakan didapatkan dari proses brainstorming dengan pihak perusahaan melalui diskusi bersama dengan orang yang ahli dan berpengalaman dalam masalah pasokan barang di CV. Sarung Indah Sejahtera, Yaitu Pemilik perusahaan, kepala bagian gudang, dan karyawan bagian pembelian bahan baku.

\subsection{Data Hasil Kuisioner}

Data hasil kuiosioner evaluasi yang diisi oleh delapan karyawan perusahaan, dan dua dari luar perusahaan dan kemudian dirangkum pembobotan priorotas kriteria dari penilaian supplier sebagai berikut :

1. Hasil kuisioner pembobotan priorotas antara kriteria

Kuisioner ini diisi oleh sepuluh orang responden yaitu pemilik perusahaan, anak pemilik perusahaan (pelaksana harian), dua orang karyawan bagian penerimaan barang, empat orang bagian produksi, serta dua orang dari eksternal perusahaan yaitu konsumen atau pengguna produk.

Untuk kriteria Delivery diberi tanda D, kriteria Kualitas dengan kode K, Kriteria Pelayanan dengan kode $\mathrm{P}$, untuk kriteria Harga dengan kode $\mathrm{H}$.

2. Hasil kuisioner pembobotan prioritas subkriteria dari kriteria delivery kode dari masing-masing subkriteria adalah : kesesuaian jumlah (A), ketepatan waktu (B), Kesesuian spesifikasi (C).

3. Hasil kuisioner pembobotan prioritas subkriteria dari kriteria kualitas Kode dari masing - masing subkriteria adalah : Garansi (A), Kualitas barang (B)

4. Hasil kuisioner pembobotan prioritas subkriteria dari kriteria pelayanan, kode dari masing - masing subkriteria adalah : Respon (A) Komunikasi (B).

5. Hasil kuisioner pembobotan prioritas subkriteria dari kriteria harga kode masing masing sub kriteria adalah : Stabilitas harga (A), kemampuan bernegoisasi (B), Kemudahan cara pembayaran (C).

6. Hasil kuisioner skala penilaian subjektif untuk variable linguistik penilaian performansi alternatif berdasarkan semua kriteria dilakukan dengan ungkapan "sangat baik", "baik", “cukup", "kurang”, “sangat kurang" yang merupakan penilaian subjektif dari responden, dan setiap variabel diindikasikan dengan TFN dalam skala 0-100. Skala variabel linguistik yang ditetapkan peneliti dapat dilihat pada tabel 4.

Tabel 4. Skala variabel linguistik penilaian performansi alternatif

\begin{tabular}{|c|c|c|c|}
\hline \multirow{2}{*}{$\begin{array}{c}\text { Variabel } \\
\text { Linguistik }\end{array}$} & \multicolumn{3}{|c|}{ TFN } \\
\hline & $L$ & $m$ & $u$ \\
\hline $\begin{array}{l}\text { Sangat kurang } \\
\text { (SK) }\end{array}$ & 0 & 0 & 20 \\
\hline Kurang (K) & 20 & 40 & 55 \\
\hline Cukup (C) & 55 & 60 & 65 \\
\hline Baik (B) & 65 & 70 & 75 \\
\hline Sangat baik (SB) & 75 & 100 & 100 \\
\hline
\end{tabular}

Tabel 5 Hasil kuisioner penilaian performansi supplier untuk setiap kriteria subjektif dari supplier 1.

\begin{tabular}{|c|c|c|c|c|c|c|c|c|c|c|}
\hline \multirow{3}{*}{ KRITERIA } & \multicolumn{10}{|c|}{ ALTERNATIF } \\
\hline & \multicolumn{10}{|c|}{ SUPPLIER 1.} \\
\hline & \begin{tabular}{|l} 
R1 \\
\end{tabular} & R2 & R3 & R4 & R5 & R6 & R7 & R8 & R9 & R10 \\
\hline Garansi & $\mathrm{C}$ & B & $\mathrm{C}$ & $\mathrm{C}$ & $\mathrm{C}$ & B & B & SB & SB & B \\
\hline Kualitas barang & B & B & B & B & B & B & B & B & B & B \\
\hline Respon & B & $\mathrm{C}$ & B & B & $\mathrm{C}$ & $\mathrm{C}$ & B & $\mathrm{C}$ & $\mathrm{C}$ & B \\
\hline Komunikasi & B & B & B & $\mathrm{K}$ & B & $\mathrm{C}$ & $\mathrm{C}$ & $\mathrm{C}$ & $\mathrm{C}$ & $\mathrm{C}$ \\
\hline kemampauan bernegoisasi & B & B & B & B & B & B & B & B & B & B \\
\hline Kemudahan cara pembayaran & $\mathrm{K}$ & B & $\mathrm{K}$ & B & $\mathrm{K}$ & $\mathrm{K}$ & $\mathrm{K}$ & B & $\mathrm{K}$ & $\mathrm{K}$ \\
\hline
\end{tabular}

Tabel 6 Hasil kuisioner penilaian performansi supplier untuk setiap kriteria subjektif dari supplier 2.

\begin{tabular}{|c|c|c|c|c|c|c|c|c|c|c|}
\hline \multirow{3}{*}{ KRITERIA } & \multicolumn{10}{|c|}{ ALTERNATIF } \\
\hline & \multicolumn{10}{|c|}{ SUPPLIER 2.} \\
\hline & R1 & R2 & R3 & R4 & R5 & R6 & R7 & R8 & R9 & R10 \\
\hline Garansi & B & B & B & B & B & B & B & SB & B & SB \\
\hline Kualitas barang & SB & SB & SB & SB & B & SB & B & B & SB & SB \\
\hline Respon & B & SB & B & B & B & $\mathrm{C}$ & B & B & B & B \\
\hline Komunikasi & B & B & B & $\mathrm{C}$ & B & B & B & B & B & B \\
\hline kemampuan bernegoisasi & $\mathrm{C}$ & $\mathrm{C}$ & $\mathrm{C}$ & $\mathrm{C}$ & $\mathrm{C}$ & B & B & $\mathrm{C}$ & B & $\mathrm{C}$ \\
\hline Kemudahan cara pembayaran & $\mathrm{K}$ & $\mathrm{C}$ & $\mathrm{K}$ & $\mathrm{K}$ & $\mathrm{K}$ & $\mathrm{C}$ & $\mathrm{C}$ & B & $\mathrm{C}$ & $\mathrm{C}$ \\
\hline
\end{tabular}

Tabel 7. Hasil kuisioner penilaian performansi supplier untuk setiap kriteria subjektif dari supplier 3 . 


\begin{tabular}{|l|l|l|l|l|l|l|l|l|l|l|}
\hline \multirow{3}{*}{ KRITERIA } & \multicolumn{10}{|c|}{ ALTERNATIF } \\
\cline { 2 - 12 } & \multicolumn{9}{|c|}{ SUPPLIER 3. } \\
\cline { 2 - 11 } & R1 & R2 & R3 & R4 & R5 & R6 & R7 & R8 & R9 & R10 \\
\hline Garansi & B & B & B & B & B & B & C & B & C & B \\
\hline Kualitas barang & B & B & B & C & C & B & B & B & B & B \\
\hline Respon & C & C & C & K & B & C & C & B & C & B \\
\hline Komunikasi & K & K & SK & SK & SK & K & SK & K & K & C \\
\hline kemampuan bernegoisasi & B & B & K & B & B & B & C & B & B & B \\
\hline Kemudahan cara pembayaran & C & C & C & C & K & B & C & B & B & B \\
& & & & & & & & & & \\
\hline
\end{tabular}

7. Data objektif dari supplier

Data objektif seluruh penilaian supplier dapat dilihat di tabel 8

Tabel 8 hasil data objektif performance supplier

\begin{tabular}{|l|c|c|c|}
\hline \multirow{2}{*}{} & \multicolumn{3}{|c|}{ SUPPLIER } \\
\cline { 2 - 4 } & 1 & 2 & 3 \\
\hline Harga & 100 & 900 & 950 \\
\hline jumlah pengiriman tidak sesuai permintaan & 2 & 2 & 2 \\
\hline jumlah pengiriman tidak tepat waktu & 4 & 2 & 3 \\
\hline jumlah tidak sesuai spesifikasi & 1 & 2 & 1 \\
\hline
\end{tabular}

\subsection{Pengolahan Data}

\section{Perhitungan bobot prioritas antar kriteria}

menghitung uji konsistensi matriks

$$
\begin{aligned}
& =(7,000 \times 0,142)+(2,033 \times 0,488) \\
& +(9,000 \times 0,144)+(4,833 \times 0,255) \\
& =0,995+0.993+1,026+1,234 \\
& =4,248 \\
& =\frac{4,248-4}{4-1} \\
& =\frac{0,248}{3} \\
& =0,083 \\
& =\underline{0,083} \\
& =0,9 \\
\text { CR } \quad & 0,092<0,100
\end{aligned}
$$

Karena CR $<0.100$ maka preferensi responden adalah konsisten

Dengan cara yang sama untuk seluruh hasil perhitungan antara kriteria diperoleh nilai CI dan CR sebagai berikut :

Tabel 9 seluruh hasil perhitungan nilai CI dan CR

\begin{tabular}{|c|c|c|}
\hline RESPONDEN & CI & CR \\
\hline 1 & 0,055 & 0,061 \\
\hline 2 & 0,054 & 0,060 \\
\hline 3 & 0,037 & 0,041 \\
\hline 4 & 0,063 & 0,071 \\
\hline 5 & 0,087 & 0,097 \\
\hline 6 & 0,084 & 0,093 \\
\hline 7 & 0,048 & 0,053 \\
\hline 8 & 0,074 & 0,082 \\
\hline 9 & 0,077 & 0,086 \\
\hline
\end{tabular}

\begin{tabular}{|l|l|l|}
\hline 10 & 0,083 & 0,092 \\
\hline
\end{tabular}

\section{Fuzzyfikasi PCM}

Setelah nilai CR dari setiap PCM diketahui dan dapat diterima atau $\mathrm{CR}<0,10$ maka langkah selanjutnya adalah mengkonversi skala bilangan menjadi skala fuzzy pada setiap PCM.

Tabel hasil Fuzzyfikasi penilaian perbandingan berpasangan antar kriteria dari responden 1 sampai responden 10 bisa dilihat di tabel 7.140 di lampiran halaman 13.

\section{Bobot Fuzzy}

Langkah selanjutnya adalah mendefinisikan ratarata geometrik fuzzy dengan rumus sebagai berikut :

$$
r=\left(\mathrm{a}_{i 1} \mathrm{x} \mathrm{a}_{i 2} \times \ldots \mathrm{xa}_{i n}\right)^{1 / n}
$$

Berikut ini adalah contoh perhitungan ratarata geometrik fuzzy untuk kriteria delivery yang pada penelitian ini diberi kode $\mathrm{D}$

$$
\begin{aligned}
r_{\text {delivery }}=[(1,000 ; 1,000 ; 1,000) \mathrm{x} \\
\\
(0,333 ; 0,433 ; 0,391) \mathrm{x} \\
(0,515 ; 0,740 ; 1,054) \mathrm{x} \\
\quad(0,799 ; 1,188 ; 1,691) \\
=\quad(0,607 ; 0,785 ; 1,013)
\end{aligned}
$$

Dengan perhitungan yang sama seperti diatas maka rata-rata geometrik fuzzy dari tiap kriteria adalah sebagai berikut :

$$
\begin{aligned}
& r_{\text {delivery }}=(0,607 ; 0,785 ; 1,013) \\
& r_{\text {kualitas }}=(1,352 ; 1,910 ; 2,295) \\
& r_{\text {pelayanan }}=(0,717 ; 0,988 ; 1,222) \\
& r_{\text {harga }}=(0,509 ; 0,666 ; 0,876)
\end{aligned}
$$

Setelah mendapatkan nilai rata-rata geometrik fuzzy dilakukan perhitungan nilai bobot fuzzy dari setiap kriteria dengan rumus sebagai berikut :

$$
\begin{aligned}
& \mathrm{w}=\mathrm{r}_{1} \times\left(\mathrm{r}_{1}+\mathrm{r}_{2}+\ldots+\mathrm{r}_{\mathrm{n}}\right)^{-1} \\
& w_{\text {delivery }}=\mathrm{r}_{\text {delivery }} \times\left(\mathrm{r}_{\text {delivery }}+\mathrm{r}_{\text {kualitas }}+\mathrm{r}_{\text {pelayanan }}+\mathrm{r}\right. \\
& \text { harga })^{-1} \\
& \left(\begin{array}{c}
\left.\mathrm{r}_{\text {delivery }}+\mathrm{r}_{\text {kualitas }}+\mathrm{r}_{\text {pelayanan }}+\mathrm{r}_{\text {harga }}\right)^{-1}= \\
(1 / 1,013+2,295+1,222+0,876) \\
(1 / 0,785+1,910+0,988+0,666) \\
(1 / 0,607+1,352+0,717+0,509)
\end{array}\right) \\
& \left(\mathrm{r}_{\text {delivery }}+\mathrm{r}_{\text {kualitas }}+\mathrm{r}_{\text {pelayanan }}+\mathrm{r}_{\text {harga }}\right)^{-1}= \\
& (0,185 ; 0,230 ; 0,314) \\
& \begin{array}{c}
w_{\text {delivery }}=(0,607 ; 0,785 ; 1,013) \times \\
(0,185 ; 0,230 ; 0,314) \\
=(0,112 ; 0,181 ; 0,318)
\end{array}
\end{aligned}
$$


Dengan perhitungan yang sama seperti diatas maka bobot fuzzy dari setiap kriteria adalah sebagai berikut :

$$
\begin{aligned}
& w_{\text {delivery }}=(0,112 ; 0,181 ; 0,318) \\
& w_{\text {kualitas }}=(0,250 ; 0,439 ; 0,721) \\
& \begin{array}{ll}
w_{\text {pelayanan }} & =(0,133 ; 0,227 ; 0,384) \\
w_{\text {harga }} & =(0,094 ; 0,153 ; 0,275)
\end{array}
\end{aligned}
$$

\subsection{Perhitungan bobot performance supplier} 1. Perhitungan bobot supplier

Tabel 10 Penilaian skala subjektif untuk variabel linguistik

\begin{tabular}{|c|c|c|c|}
\hline Variabel & \multicolumn{3}{|c|}{ TFN } \\
\cline { 2 - 4 } Linguistik & $i$ & $m$ & $u$ \\
\hline $\begin{array}{c}\text { Sangat kurang } \\
\text { (SK) }\end{array}$ & 0 & 0 & 20 \\
\hline Kurang (K) & 20 & 40 & 55 \\
\hline Cukup (C) & 55 & 60 & 65 \\
\hline Baik (B) & 65 & 70 & 75 \\
\hline Sangat baik (SB) & 75 & 100 & 100 \\
\hline
\end{tabular}

Dari hasil penilaian alternatif untuk setiap subkriteria, dilakukan perhitungan rata-rata fuzzy performance dengan rumus matematis sebagai berikut: $E_{i j}=(1 / n) x\left(E_{i j}^{1}+E_{i j}^{2}+\ldots . . E_{i j}^{n}\right)$.

Pada perhitungan rata-rata fuzzy performance untuk subkriteria subjektif akan menggunakan skala penilaian subjektif tabel 4.2.112. sedangkan untuk penilaian kriteria objektif akan menggunakan skala penilaian objektif variabel linguistik. Berikut adalah contoh perhitungan rata-rata fuzzy performance.

Perhitungan rata-rata fuzzy performance untuk supplier 1.Penialain terhadap supplier 1 untuk kriteria garansi dari responden $1 \mathrm{~s} / \mathrm{d}$ responden 10 adalah $\mathrm{C}, \mathrm{B}, \mathrm{C}, \mathrm{C}, \mathrm{C}, \mathrm{B}, \mathrm{B}, \mathrm{SB}, \mathrm{SB}, \mathrm{B}$

$$
\begin{aligned}
E_{\text {garansi }}=\quad & 1 / 10 \times(55 ; 60 ; 65)+(65 ; 70 ; 75) \\
& +(55 ; 60 ; 65)+(55 ; 60 ; 65)+ \\
& (55 ; 60 ; 65)+(65 ; 70 ; 75)+ \\
& (65 ; 70 ; 75)+(75 ; 100 ; 100)+ \\
& (75 ; 100 ; 100)+(55 ; 60 ; 65) \\
= & (63 ; 72 ; 76)
\end{aligned}
$$

Dengan cara yang sama, berikut ini adalah hasil nilai performance supplier untuk kriteria subjektif

Tabel 11 Konversi penilaian performance supplier kriteria subjektif ke skala fuzzy

\begin{tabular}{|l|c|c|c|c|c|c|c|c|c|}
\hline \multirow{3}{*}{\multicolumn{1}{c|}{ Kriteria }} & \multicolumn{10}{|c|}{ Supplier } \\
\cline { 2 - 10 } & \multicolumn{3}{|c|}{1} & \multicolumn{3}{c|}{2} & \multicolumn{3}{c|}{3} \\
\cline { 2 - 10 } & $i$ & $m$ & $u$ & $i$ & $m$ & $u$ & $i$ & $m$ & $u$ \\
\hline Garansi & 63 & 72 & 76 & 67 & 76 & 80 & 63 & 68 & 73 \\
\hline Kualitas barang & 65 & 70 & 75 & 72 & 91 & 92,5 & 63 & 68 & 73 \\
\hline Respon & 60 & 65 & 70 & 65 & 72 & 76,5 & 54,5 & 61 & 67 \\
\hline Komunikasi & 55,5 & 62 & 68 & 64 & 69 & 74 & 15,5 & 26 & 42 \\
\hline Pemberian diskon & 65 & 70 & 75 & 58 & 63 & 68 & 59,5 & 60 & 72 \\
\hline Kemudahan cara pembayaran & 33,5 & 49 & 61 & 42 & 53 & 62 & 55,5 & 62 & 68 \\
\hline
\end{tabular}

Agar dapat dilakukan penilaian secara kuantitatif, penilaian dilakukan berdasarkan dengan skala linguistik dengan rincian untuk masing-masing skala berdasarkan kesepakatan dengan responden.

Tabel 12 penilaian performance supplier untuk seluruh subkriteria dengan nilai BNP

\begin{tabular}{|l|c|c|c|}
\hline \multirow{2}{*}{\multicolumn{1}{|c|}{ Kriteria }} & \multicolumn{3}{c|}{ BNP } \\
\cline { 2 - 4 } & \multicolumn{3}{c|}{ Supplier } \\
\cline { 2 - 4 } & 1 & 2 & 3 \\
\hline Garansi & 70,33 & 74,33 & 68 \\
\hline Kualitas barang & 70 & 85,17 & 68 \\
\hline Respon & 65 & 71,17 & 60,83 \\
\hline Komunikasi & 61,83 & 69 & 27,83 \\
\hline Pemberian diskon & 70 & 63 & 63,83 \\
\hline Kemudahan cara & 47,83 & 52,33 & 61,83 \\
pembayaran & & & 75 \\
\hline Stabilitas Harga & 50 & 93,33 & 75 \\
\hline kesesuaian jumlah & 75 & 75 & 50 \\
\hline ketepatan waktu & 25 & 75 & 75 \\
\hline kesesuaian spesifikasi & 75 & 50 & \\
\hline
\end{tabular}

\section{Penentuan supplier terbaik}

Penentuan supplier terbaik diindikasikan oleh fuzzy synthetic decision $(R)$ yaitu jumlah hasil perkalian antara nilai fuzzy performance alternatif dari tiap-tiap kriteria $(E)$ dengan bobot kriteria tersebut (w). fuzzy synthetic decision dapat diperoleh dengan rumus matematis $\mathrm{R}=\mathrm{E} * \mathrm{w}$. Pendekatan nilai fuzzy $\mathrm{R}_{\mathrm{i}}$ terwakili oleh

$$
\begin{aligned}
& \mathrm{R}_{\mathrm{i}}=\left(1 \mathrm{R}_{\mathrm{i}} ; \mathrm{mR}_{\mathrm{i}} ; \mathrm{uR} \mathrm{R}_{\mathrm{i}}\right), \text { dimana } \\
& 1 \mathrm{R}=\sum_{j-i}^{n} 1 E_{\mathrm{ij}} \mathrm{X} 1 w_{j}, \\
& \mathrm{mR}=\sum_{j-i}^{n} \mathrm{~m} E_{\mathrm{ij}} \mathrm{x} \mathrm{m} w_{j}, \\
& \mathrm{uR}=\sum_{j-i}^{n} \mathrm{u} E_{\mathrm{ij}} \mathrm{X} \mathrm{u} w_{j},
\end{aligned}
$$$$
\text { untuk supplier } 1 \text { nilai fuzzy fuzzy }
$$

synthetic decision-nya adalah :

$$
\begin{aligned}
& R_{l}=[(0,07 ; 0,17 ; 0,70) \times(63,00 ; 72,00 ; 76,00)]+ \\
& {[(0,11 ; 0,27 ; 0,65) \times(65,00 ; 70,00 ; 75.00)]+} \\
& {[(0,04 ; 0,10 ; 0,25) \times(60,00 ; 65,00 ; 70,00)]+} \\
& {[(0,05 ; 0,12 ; 0,31) \times(55,50 ; 62,00 ; 68,00)]+} \\
& {[(0,02 ; 0,05 ; 0,30) \times(65,00 ; 70,00 ; 75,00)]+}
\end{aligned}
$$


$[(0,01 ; 0,04 ; 0,10) \times(33,50 ; 49,00 ; 61,00)]+$ $[(0,02 ; 0,06 ; 0,15) \times(30,00 ; 50,00 ; 70,00)]+$ $[(0,02 ; 0,07 ; 0,27) \times(60,00 ; 75,00 ; 90,00)]+$ $[(0,03 ; 0,08 ; 0,21) \times(10,00 ; 25,00 ; 40,00)]+$ $[(0,01 ; 0,03 ; 0,10) \times(60,00 ; 75,00 ; 90,00)]$ $=(21,07 ; 63,04 ; 221,33)$

$\mathrm{R}_{2}=[(0,07 ; 0,17 ; 0,70) \times(67,00 ; 76,00 ; 80,00)]+$ $[(0,11 ; 0,27 ; 0,65) \times(72,00 ; 91,00 ; 92,50)]+$ $[(0,04 ; 0,10 ; 0,25) \times(65,00 ; 72,00 ; 76,50)]+$ $[(0,05 ; 0,12 ; 0,31) \times(64,00 ; 69,00 ; 74,00)]+$ $[(0,02 ; 0,05 ; 0,30) \times(58,00 ; 63,00 ; 68,00)]+$ $[(0,01 ; 0,04 ; 0,10) \times(42,00 ; 53,00 ; 62,00)]+$ $[(0,02 ; 0,06 ; 0,15) \times(80,00 ; 100,00 ; 100,00)]+$ $[(0,02 ; 0,07 ; 0,27) \times(60,00 ; 75,00 ; 90,00)]+$ $[(0,03 ; 0,08 ; 0,21) \times(60,00 ; 75,00 ; 90,00)]+$ $[(0,01 ; 0,03 ; 0,10) \times(30,00 ; 50,00 ; 70,00)]$

$$
=(24,89 ; 76,99 ; 249,99)
$$

$\mathrm{R}_{3}=[(0,07 ; 0,17 ; 0,70) \times(63,00 ; 68,00 ; 73,00)]+$ $[(0,11 ; 0,27 ; 0,65) \times(63,00 ; 68,00 ; 73,00)]+$ $[(0,04 ; 0,10 ; 0,25) \times(54,50 ; 61,00 ; 67,00)]+$ $[(0,05 ; 0,12 ; 0,31) \times(15,50 ; 26,00 ; 42,00)]+$ $[(0,02 ; 0,05 ; 0,30) \times(59,50 ; 60,00 ; 72,00)]+$ $[(0,01 ; 0,04 ; 0,10) \times(55,50 ; 62,00 ; 68,00)]+$ $[(0,02 ; 0,06 ; 0,15) \times(60,00 ; 75,00 ; 90,00)]+$ $[(0,02 ; 0,07 ; 0,27) \times(60,00 ; 75,00 ; 90,00)]+$ $[(0,03 ; 0,08 ; 0,21) \times(30,00 ; 50,00 ; 70,00)]+$ $[(0,01 ; 0,03 ; 0,10) \times(60,00 ; 75,00 ; 90,00)]$

$$
=(19,94 ; 60,62 ; 218,22)
$$

\section{Fuzzy Rangking}

Hasil dari fuzzy synthentic decision merupakan bilangan fuzzy, dan harus didefuzzyfikasi menjadi nilai best non-fuzzy performance (BNP) yang akan menunjukkan tingkat prioritas dari setiap alternatif. BNP tertinggi merupakan performance terbaik. Perhitungan BNP menggunakan metode center of area (COA) dengan rumus matematis sebagai berikut :

$$
\begin{aligned}
& B N P i=[\{(u R i-1 R i)+(m R i-1 R i)\} / \\
3]+1 R i & \\
B N P_{1}= & =[\{(221,33-21,07)+(63,221-21,07)\} / 3] \\
21,07 & =101,81 \\
B N P_{2} & =[\{(249,99-24,89)+(76,99-24,89)\} / 3]+ \\
24,89 & =117,29 \\
B N P_{3} & =[\{(218,22-19,94)+(60,62-19,94)\} / 3]+ \\
19,94 & \\
= & 99,59
\end{aligned}
$$

\section{ANALISA DAN PEMBAHASAN}

\subsection{Analisis Peringkat Prioritas Kriteria}

Dari hasil pengolahan dan perhitungan data dengan menggunakan metode fuzzy AHP, dapat dibuat suatu analisis untuk menjadi masukkan dan pertimbangan bagi perusahaan untuk menentukan supplier terbaik. Terdapat banyak kriteria pemilihan yang harus diperhatikan dakam pemilihan supplier. Dari kriteria-kriteria yang terlibat dalam pemilihan memiliki tingkat prioritas yang berbeda antara satu kriteria dengan kriteria lainnnya. Tingkat prioritas ini yang akan menunjukkan seberapa penting kriteria tersebut.
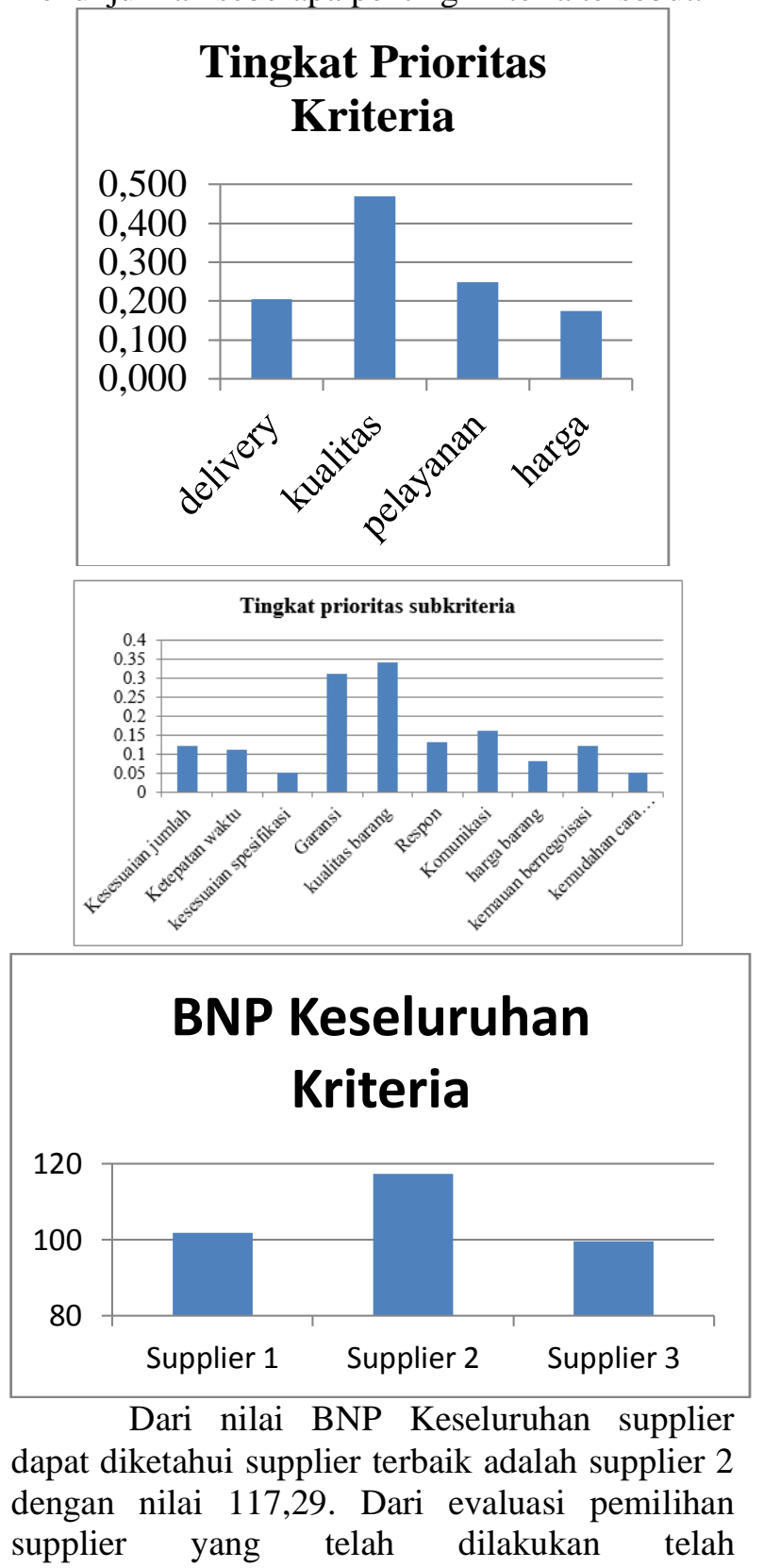
mempertimbangkan kriteria-kriteria yang dianggap mampu menilai supplier secara komprehensif sepery delivery, kualitas, pelayanan dan harga. Oleh karena itu hasil pemilihan supplier diatas diharapkan dapat memberikan maanfaat bagi perusahaan sebagai berikut :

1. Meningkatkan kualitas produk yang dijual, karena dngan evaluasi pemilihan supplier diharapkan dapat menjaga kualitas barang yang menjadi input meningkatkan keuntungan perusahaan.

2. Kualitas bahan baku yang baik akan membuat produk yang dihasilkan juga ikut baik, sehinggan para konsumen atau para pemakai merasa nyaman dan akan memilih produk kita kembali.

3. Dapat menekan biaya karena semakin kecilnya biaya pengadaan barang.

\section{KESIMPULAN DAN SARAN \\ 6.1 Simpulan}

Berdasarkan hasil perhitungan, analisis dan pembahasan yang telah dilakukan, maka dapat diambil kesimpulan sebagai berikut :

1. Dari hasil perhitungan kriteria - kriteria yang menjadi prioritas dalam proses pemilihan supplier benang di CV Sarung Indah Sejahtera adalah kriteria Kualitas dengan subkriteria kualitas barang dan garansi.

2. Berdasarkan hasil pembobotan yang dilakukan dengan metode Fuzzy Analytical Hierarcy Process (AHP). Supplier 2 memiliki bobot prioritas terbesar yaitu 117,29 dibandingkan dengan supplier lainnya, hal ini ditunjukkan dengan tingginya bobot supplier 2 dalam beberapa aspek kriteria seperty subkriteria kualitas barang, garansi, respon, komunikasi, harga, dan ketepatan waktu. Hal ini berarti supplier yang mempunyai kinerja terbaik dalam menyediakan pasokan barang untuk $\mathrm{CV}$ sarung indah sejahtera adalah supplier 2 .

\subsection{Saran}

Untuk penelitian selanjutnya, ada beberapa saran yang dapat dijadikan pertimbangan bagi perusahaan dan penelitian selanjutnya. Saransaran yang dapat diberikan penulis adalah sebagai berikut :

1. Pengambilan keputusan harus lebih memperhatikan dan mempertimbangkan kriteria-kriteria untuk pemilihan supplier dengan pertimbangan yang lebih baik dan objektif agar pemilihan supplier mendapatkan solusi yang optimal.

2. Penerapan metode AHP dan Fuzzy AHP pada kasus-kasus lain diperusahaan selain pemilihan pemasok.

\section{DAFTAR PUSTAKA}

Agarwal, A. dan Ravi, S. 2005. Modeling Supply Chain Performance Variance Variables. Asian Academy of Management Journal.

Juwita. 2010. Sitem Pendukung Keputusan Balance Scorecard Berbasis Web Untuk Pengukuran Kinerja Fakultas Matematika Dan Ilmu Pengetahuan Alam (MIPA) Universitas Syiah Kuala.

Kotler, Philip. 2005. Corporate Sosial Responsibility, Doing The Most Good Your Company And Your Cause, John Willey, Sons Publisher.

L. Saaty, Thomas. 1993. Pengambilan Keputusan Bagi Para Pemimpin. Jakarta: PT Pustaka Binaman Presindo.

Mulyono, Sri. 1996. Teori Pengambilan Keputusan Edisi Revisi. Fakultas Ekonomi Universitas Indonesia : Jakarta.

Oktavitri, Nur Indradewi. 2008. Analisis Manajemen Risiko Lingkungan Limbah Berbahan Berbahaya Dan Beracun (B3) Berdasarkan Peniliaian Risiko Dengan Fuzzy Analytical Hierarchy Process (FAHP) (studi Kasus : Lumpur B3 PT A dan PT B). Surabaya : Teknik Industri, Institut Teknologi Sepuluh November.

Prima, Juwita. 2010. Analisis Dan Perencanaan Sistem Informasi Pengadaan Bahan Baku (EProcurement) Dan Evaluasi Supplier Pada Pt. Kabelindo Murni Tbk, Dengan Metode Fuzzy Ahp. Jakarta : Teknik Industri Dan Sistem Informasi, Universitas Bina Nusantara.

Pengertian Supplier. Web 17 November 2013. .http://dutamahinsani.com/?ForceFlash=true \#/submenu/Supplier.html

Rif'an Muhammad. 2014. Analisa Pemilihan Pemasok Sayuran Dengan Metode Analytic Hierarvhy Prosecess (AHP) Dan Fuzzy. Teknik Industri, Universitas Muhammadiyah Gresik.

Saaty L. Thomas. 1988. Decision, Making for Laders; The Analytical Hierarchy Process for Decision in Complex World. 
Sri Kusumadewi dan Hari Purnomo. 2010. Aplikasi Logika Fuzzy Untuk Pendukung Keputusan, Edisi 2. Yogyakarta: Graha Ilmu.

Sri Kusumadewi, Sri Hartati, Agus Harjoko dan Retanto Wardoyo. 2006. Fuzzy MultiAttribute Decision Making (Fuzzy $M A D M)$. Yogyakarta: Graha Ilmu.

Sulistiana Winda dan Yulianawati Evi. 2010. Analisis Pemilihan Supplier Bahan Baku Dengan Menggunakan Metode Fuzzy Anlytical Hierarchy process (FAHP). Jurusan Teknik Industri, Fakultas teknologi Industri, Institut Teknologi Adhi Tama Surabaya.

Tandellin E. 2010. Analisis Investasi dan Manajemen Portofolio, Edisi Kelima. Yogyakarta.

Weber, C.A, Current, J.R, \& benton, W,C. 1991. Vendor Selections Criteria And Methods, European Journal of Operational Research. Vol. 50. Hal. 2-18.

Viarani Suci Oktri dan Raimona Hilda Zadry. 2015. Analisis pemilihan pemasok dengan metode analytical hierarchy proses di proyek indarung vi PT Semen Padang. Jurusan teknik Industri, fakultas teknik, universitas andalas, padang. 